\title{
Lung cancer risk and talc not containing asbestiform fibres: a review of the epidemiological evidence
}

\section{P Wild}

Occup Environ Med 2006;63:4-9. doi: 10.1136/oem.2005.020750

A literature search was done and all epidemiological cancer studies mentioning talc as a risk factor were selected. The talc exposed populations were divided into three groups: (1) populations in which no other occupational carcinogen was mentioned (only talc millers satisfied this criterion); (2) populations of talc miners exposed to talc, quartz, and/or radon; and (3) other industrial populations in which talc is associated with quartz, nitrosamines, and asbestos depending on the study. No excess lung cancer mortality was found for the populations of talc millers exposed to high levels of talc but without any other potential carcinogen (SMR $=0.92,42$ cases) while the summary of mortality of talc miners exposed to quartz and/or radon was in excess (fixed effect $S M R=1.20$, random effect $R R=1.85,40$ cases). Six studies in other industrial settings were identified. All reported increased lung cancer mortality among talc exposed workers but the talc exposure was confounded with other carcinogens and only one study was able to adjust on them. In conclusion, no increased lung cancer mortality was observed among talc millers despite their high exposure experience. In populations in which talc was associated with other potential carcinogens, some lung cancer excesses were observed.

\footnotetext{
Correspondence to:

Dr P Wild, INRS

Département

Epidémiologie en

Entreprises, BP 27, 54501

Vandoeuvre Cedex,

France; pascal.wild@inrs.
}

Accepted 16 June 2005
$\mathrm{T}$ he talc mineral $\left(\mathrm{Mg}_{3} \mathrm{Si}_{4} \mathrm{O}_{10}(\mathrm{OH})_{2}\right)$, is a member of the silicate family but its physical and chemical properties are very different from those of asbestos minerals or of crystalline silica. $^{1-3}$ These differences are mainly linked to their crystalline structure. The talc mineral is characterised by its two dimensional structure in sheets separated by slight forces. This explains the platy shape of talc particles and its smoothness in touch (hardness 1 on the Mohs scale) for which it is valued in industrial applications. Talc is also characterised by its hydrophobic property and its very low solubility. When milled, some cleavage fragments within the talc powder meet the WHO definition of fibres, although in fact these particles are elongated talc platelets. These "fibres" have low aspect ratios (usually 3-10) and have been shown to make up to $1 \%$ of the powder.

Asbestos minerals can be separated in two silicate families. Tremolite-actinolite $\left(\mathrm{Ca}_{2}\right.$ $(\mathrm{Mg}, \mathrm{Fe})_{5} \mathrm{Si}_{8} \mathrm{O}_{22}(\mathrm{OH})_{2}$, anthophyllite $\left((\mathrm{Mg}, \mathrm{Fe})_{7}\right.$
$\left.\mathrm{Si}_{8} \mathrm{O}_{22}(\mathrm{OH})_{2}\right)$, amosite $\left((\mathrm{Mg}, \mathrm{Fe})_{7} \mathrm{Si}_{8} \mathrm{O}_{22}(\mathrm{OH})_{2}\right)$, and crocidolite $\left(\mathrm{Na} 2 \mathrm{Fe}^{2+}{ }_{3} \mathrm{Fe}^{3+}{ }_{2} \mathrm{Si}_{8} \mathrm{O}_{22}(\mathrm{OH})_{2}\right)$ belong to the amphibole family characterised by a one dimensional chain structure. Chrysotile $\left(\mathrm{Mg}_{3} \mathrm{Si}_{2} \mathrm{O}_{5}(\mathrm{OH})_{4}\right)$ belongs, like talc, to the sheet silicate family but it is characterised by its very typical scrolled structure of the layers. The asbestos minerals exhibit a higher hardness (5-6 for amphibole asbestos, 2-4 for chrysotile). Quartz, the only form of crystalline silica possibly associated with talc ore, is characterised by a three dimensional structure with strong bonding explaining its high hardness ( 7 on the Mohs scale) and its great abrasiveness.

As talc mineral and asbestos minerals are composed of the same chemical elements ( $\mathrm{Si}$, $\mathrm{Mg}, \mathrm{Fe}$, and more or less $\mathrm{Ca})$, they can be found in neighbouring geological environments. During the genesis of the deposits and depending of the pressure and temperature conditions, talc or asbestos could both grow but only exceptionally in the same deposit. For example, mineral talc is generated during the slow hydrothermal transformation of calcareo-magnesian rocks (dolomite, magnesite) or of ultramafic rocks (peridotite, amphibolite). In the first case talc is mainly associated with chlorite and calcite and exceptionally with tremolite. In the second case, talc is mainly associated with serpentine and chlorite and exceptionally with actinolite and anthophyllite.

The extracted talc ore never consists of a pure talc mineral. Thus the products marketed as talc are in fact mixtures of $50 \%$ to $90 \%$ talc and other minerals, depending on the deposit and its geological origin. An extreme case is the New York state talc which contains only about $25 \%$ of the talc mineral. The associated minerals in this deposit (tremolite, anthophyllite, and serpentine) have been described as existing at least partially as asbestiform fibres. The term asbestiform refers to the unusual crystallisation habit of a mineral in which the crystals are thin, hair-like (single dimensional) fibres with enhanced strength, flexibility, and durability.

In its 1987 review, the International Agency for Research on Cancer (IARC) ${ }^{3}$ separated the talcs containing and not containing asbestiform fibres. It concluded that there was sufficient evidence for the carcinogenicity to humans of talc containing asbestiform fibres based on a series of epidemiological studies conducted in the populations of talc workers in New York

Abbreviations: IARC, International Agency for Research on Cancer; NMRD, non-malignant respiratory diseases 
State, and that there was inadequate evidence for the talc not containing asbestiform fibres.

The latter assessment was based on four epidemiological studies among miners and millers of talc: Selevan, ${ }^{4}$ Rubino, ${ }^{5}$ Léophonte, ${ }^{6}$ and Kastnelson. ${ }^{7}$ The last three were considered not to be interpretable because of their non-standard methodology.

The purpose of this paper is to update the evidence as to the lung carcinogenicity of talc not containing asbestiform fibres in the light of a series of recently published epidemiological studies. It also updates the more recent (2000) unpublished 10th Report on Carcinogens of the US National Toxicology Program (10th RoC) which did however not reach a final conclusion with respect to talc.

\section{MATERIALS AND METHODS}

A literature search was done in the online reference database PubMed of the National Library of Medicine, updating the references included in the IARC review. The last reference included in the IARC review was published in 1983, so the literature search was considered complete until this date. The keywords used in the database search were "talc and lung cancer" and "talc and epidemiology". The papers cited in the selected papers and in the background document of the 10th RoC on talc were also considered.

Included were all papers with original information (comments and editorials were excluded) giving information of the lung cancer mortality of populations exposed to talc. Excluded were studies mentioning fibrous talc or studying New York talc populations as well as papers concerned with the medical use of talc in the treatment of malignant tumours (talc pleurodesis). Some of the authors of the selected papers were contacted in order to obtain complementary information.

The study populations were classified into one of three groups:

1. Populations in which no other occupational carcinogen was mentioned (only talc millers satisfied this criterion).

2. Population of talc miners exposed to talc, quartz, and/or radon.

3. Other industrial populations in which talc is associated with quartz, nitrosamines, aromatic amines, and asbestos depending on the study.

A test of heterogeneity of standardised mortality ratios (SMRs) and a summary (fixed effect) SMR was performed as described in Breslow and Day ${ }^{8}$ when only SMRs were combined. When significant heterogeneity was detected, a random effect estimate and corresponding confidence intervals were computed as described in Sutton et al. ${ }^{9}$

\section{RESULTS}

Thirty nine papers were identified using keywords "talc, lung cancer and epidemiology". Two other relevant papers were identified when using "talc and cancer" or "talc and epidemiology" as keywords.

Out of these 41 papers, nine papers were published before 1983 and were thus covered by the IARC review. As mentioned in the introduction, the single paper among those nine considered relevant by the IARC and whose results will be included in the present review is the paper by Selevan. ${ }^{4}$ Eleven further papers were about short term effects of talc pleurodesis, two were reviews or comments on results, one was a toxicology report on animals, two papers described case series, three papers showed updates of the New York talc studies, leaving 13 papers for closer scrutiny.

Stern et al gave the results of a PMR study of 12873 deceased unionised construction plasterers and cement masons. ${ }^{10}$ Given the inadequate methodology and the lack of a specific talc exposure, this paper was not considered further. McDonald et al compared the fibre types in the lung tissue of mesothelioma patients and in a series of referents. ${ }^{11}$ They found no difference in the content of talc fibres between the two series. However, as this paper gives no direct estimate of a cancer risk in relation to talc exposure, it will not be further commented on.

The remaining papers described the mortality of cohorts of occupationally exposed workers: a cohort of pottery workers exposed to talc and silica, ${ }^{12}{ }^{13}$ a cohort study in a Chinese rubber factory in which talc was used, ${ }^{14}$ a mortality and cancer morbidity follow up of Norwegian talc miners and millers, ${ }^{15}$ a cohort of employees of a fibreglass manufacturing facility, ${ }^{16}$ a cohort mortality study of German rubber workers exposed to talc and asbestos, ${ }^{17}{ }^{18}$ a mortality cohort of women in the Russian printing industry, ${ }^{19}$ a cohort of women in the Norwegian pulp and paper industry, ${ }^{20}$ a mortality cohort study of French and Austrian talc workers, ${ }^{21}$ and a mortality cohort updating the Italian talc workers cohort. ${ }^{22}$

Table 1 summarises the main study population characteristics of the papers describing the mortality of talc producing companies. The mortality of talc workers from Vermont, ${ }^{4}$ Norway, ${ }^{15}$ Austria, France, ${ }^{21}$ and Italy ${ }^{22}$ was compared to local or national rates. Within these studies, miners usually have a co-exposure to silica and/or radon with the possible exception of the Norwegian miners. On the other hand, no co-exposure to other carcinogens is mentioned among talc millers. A somewhat special situation occurred among Austrian talc workers as one of the sites (D) was not exposed to talc but to a mineral (leucophylite) containing 33\% quartz. However, the mortality of talc workers not exposed to quartz (sites B and D) can be obtained from an unpublished report (Haidinger $G$, Wild P, Leodolter K, et al. Mortality patterns among French and Austrian talc workers. 2000) In order to compare the exposure levels, a conversion of mppcf (million particles per cubic foot) used in the past in Italy is necessary. Such a conversion is controversial as it depends on the fraction collected and the particle size distribution within the fraction. A tentative conversion factor of $15 \mathrm{mppcf}=2 \mathrm{mg} / \mathrm{m}^{3}$ for particles $<5 \mu \mathrm{m}$ has been proposed by the American Conference of Governmental Industrial Hygienists (ACGIH) in 1981. For the Italian workers one could rely on the fourfold decrease in number of particles measured among millers between 1960 and 1975 and assume that the exposure was stable until the first gravimetric determinations in the early 1990s. Thus one can safely assume that the exposure levels in the $1960 \mathrm{~s}$ were at least four times higher than $1.23 \mathrm{mg} / \mathrm{m}^{3}$ measured in 1993. Applying such rules, one can consider that the French talc millers were by far the most exposed group followed by the Austrian, Norwegian, and Vermont miners, with the Italian millers appearing to be the least exposed ones. In any case, the exposure in all the studies has been higher (and sometimes considerably so) than the present threshold limit values.

Additional smoking information could be obtained for the Italian talc workers (personal communication of Dr Coggiola), for the Austrian talc workers (Pfeiffer $K$, Schmidt H. Cross sectional Studie bei 38 Arbeitnehmern der Talkmühle Oberfeistritz. 1989) and for the French talc workers. ${ }^{23}$ Smoking prevalence was high and higher than in the reference populations when the data were available.

Table 2 summarises the main study population characteristics of the papers describing the mortality of talc exposed populations in other industries. Zhang et al ${ }^{14}$ and Straif et $a l^{17}{ }^{18}$ describe populations of rubber workers in which talc has been used. While Zhang et al do not identify any exposure to potential carcinogens likely to occur in rubber factories, Straif et al developed an internal job exposure matrix with semiquantitative levels for all major exposures. Chiazze et al report talc exposure in a glass fibre facility along with other 
Table 1 Summary characteristics of talc exposed populations in talc producing companies

\begin{tabular}{|c|c|c|c|c|}
\hline Study & Cohort definition & Talc exposure & Other & Smoking \\
\hline $\begin{array}{l}\text { Selevan et al, talc } \\
\text { miners }^{4}\end{array}$ & $\begin{array}{l}\text { All male talc miners radiographed in annual surveys of } \\
\text { workers in dusty trade in Vermont (US), from five companies } \\
\text { with at least one year employment between } 1940 \text { and } 1969 \text {, } \\
\text { followed up from 1940-75 }\end{array}$ & $\begin{array}{l}\text { No information } \\
\text { Levels }>20 \text { mppcf not } \\
\text { uncommon }\end{array}$ & $\begin{array}{l}\text { Radon (up to } \\
1.2 \mathrm{WL}=240 \mathrm{pCi} / \mathrm{l} \text { ), } \\
\text { possibly tremolite }\end{array}$ & No information \\
\hline $\begin{array}{l}\text { Selevan et al, talc } \\
\text { millers }^{4}\end{array}$ & $\begin{array}{l}\text { All male talc millers radiographed in annual surveys of } \\
\text { workers in dusty trade in Vermont (US), from five companies } \\
\text { with at least one year employment between } 1940 \text { and } 1969 \text {, } \\
\text { followed up from 1940-75 }\end{array}$ & $\begin{array}{l}\text { No information } \\
\text { Levels }>20 \text { mppcf not } \\
\text { uncommon }\end{array}$ & $\begin{array}{l}\text { None, } \\
\text { quartz }<0.25 \%\end{array}$ & No information \\
\hline $\begin{array}{l}\text { Wergeland et al, talc } \\
\text { miners }^{15}\end{array}$ & $\begin{array}{l}\text { All male employees from a Norwegian mine with at least } \\
\text { one year employment between } 1944 \text { and } 1972 \text { followed } \\
\text { up from 1953-87 }\end{array}$ & $\begin{array}{l}\text { In 1980: } \\
0.94-97.35 \mathrm{mg} / \mathrm{m}^{3} \\
\text { peak at } 319 \mathrm{mg} / \mathrm{m}^{3} \\
0.2-0.9 \mathrm{f} / \mathrm{ml}\end{array}$ & $3.5 \mathrm{pCi} / \mathrm{I}$ radon & $\begin{array}{l}76 \% \text { smokers in } \\
1981\end{array}$ \\
\hline $\begin{array}{l}\text { Wergeland et al, talc } \\
\text { millers }^{15}\end{array}$ & $\begin{array}{l}\text { All male employees from a Norwegian talc mill with at least } \\
\text { two years employment between } 1935 \text { and } 1972 \text { followed } \\
\text { up from 1953-87 }\end{array}$ & $\begin{array}{l}\text { In } 1980: \\
1.4-54.1 \mathrm{mg} / \mathrm{m}^{3} \text { peak } \\
\text { at } 109 \mathrm{mg} / \mathrm{m}^{3} \\
0.2-0.9 \mathrm{f} / \mathrm{ml}\end{array}$ & None & No information \\
\hline $\begin{array}{l}\text { Wild et al, French talc } \\
\text { millers }\end{array}$ & $\begin{array}{l}\text { All male employees from a French talc mill (site A) with } \\
\text { at least one year employment between } 1945 \text { and } 1994 \\
\text { followed up from 1968-95 }\end{array}$ & $\begin{array}{l}>30 \mathrm{mg} / \mathrm{m}^{3} \text { in } \\
\text { production until the } \\
1970 \mathrm{~s}, 5-30 \mathrm{mg} / \mathrm{m}^{3} \\
\text { until } 1990,<5 \mathrm{mg} / \mathrm{m}^{3} \\
\text { since except some } \\
\text { dusty jobs }\end{array}$ & $\begin{array}{l}\text { None, } \\
\text { quartz }<3 \% \text {. Some } \\
\text { workers had past } \\
\text { quartz exposure in } \\
\text { former jobs }\end{array}$ & $\begin{array}{l}59 \% \text { present smokers } \\
\text { in } 1989 ; 39 \% \text { in a } \\
\text { French population } \\
\text { survey in } 1986\end{array}$ \\
\hline $\begin{array}{l}\text { Wild et al, Austrian } \\
\text { talc millers and } \\
\text { miners }\end{array}$ & $\begin{array}{l}\text { All male workers of an Austrian talc producing company } \\
\text { having been employed at least one year in three mines } \\
\text { (site B to D) and mills or in the head office (site E) between } \\
1972 \text { and } 1995 \text { followed up from 1972-95. }\end{array}$ & $\begin{array}{l}>30 \mathrm{mg} / \mathrm{m}^{3} \text { in sites } B \\
\text { and C before } 1960 \\
\text { and for millers in D } \\
1970-80,5-30 \mathrm{for} \\
\text { millers } 1960-80 \text {, } \\
<5 \text { since } 1980\end{array}$ & $\begin{array}{l}\text { Quartz (and no talc) } \\
\text { in site D and in } \\
\text { miners of site B } \\
\text { until } 1960 \\
\text { Elsewhere quartz } \\
<3 \%\end{array}$ & $\begin{array}{l}42 \% \text { smokers in } \\
1988 ; 16 \% \text { ex- } \\
\text { smokers in } \\
\text { site B }\end{array}$ \\
\hline $\begin{array}{l}\text { Coggiola et al, Italian } \\
\text { talc miners }\end{array}$ & $\begin{array}{l}\text { All male employees from Italian talc mine with at least } \\
\text { one year employment between } 1946 \text { and } 1995 \text { followed } \\
\text { up from 1946-95 }\end{array}$ & $\begin{array}{l}\text { Decreased from more } \\
\text { than } 200 \text { mppcf in } \\
1950 \text { to less than } 5 \\
\text { mppcf in } 1965 \text { (Rubino } \\
1979 \text { ) }\end{array}$ & $\begin{array}{l}\text { High quartz in the } \\
\text { past. } \\
\text { Radon in } 1992 \\
500 \mathrm{~Bq} / \mathrm{m}^{3}= \\
13.5 \mathrm{pCi} / \mathrm{l}\end{array}$ & $\begin{array}{l}47 \% \text { smokers in } \\
1993 ; 34 \% \text { in an } \\
\text { adult Italian } \\
\text { population survey in } \\
1994\end{array}$ \\
\hline $\begin{array}{l}\text { Coggiola et al, Italian } \\
\text { talc millers }{ }^{22}\end{array}$ & $\begin{array}{l}\text { All male employees from Italian talc mill with at least one } \\
\text { year employment between } 1946 \text { and } 1995 \text { followed up from } \\
1946-95\end{array}$ & $\begin{array}{l}\text { Decreased from about } \\
20 \text { mppcf until } 1960 \text { to } \\
\text { about } 5 \text { mppcf in } 1975 \\
\text { (Rubino } 1979 \text { ). In } 1993 \\
1.3 \mathrm{mg} / \mathrm{m}^{3} \text { (personal } \\
\text { communication) }\end{array}$ & $\begin{array}{l}\text { None } \\
\text { Quartz }<1 \%\end{array}$ & $\begin{array}{l}44 \% \text { smokers in } \\
1993 ; 34 \% \text { in an } \\
\text { adult Italian } \\
\text { population survey in } \\
1994\end{array}$ \\
\hline
\end{tabular}

exposures. ${ }^{16}$ Four different levels (in $\mathrm{f} / \mathrm{ml}$ ) were estimated from an internal job-time period exposure matrix. The job history of each study member was converted in a cumulative exposure in days $\times \mathrm{f} / \mathrm{l}$ which was used to estimate risk in nested case control studies of lung cancer and non-malignant respiratory diseases. A conversion from $\mathrm{f} / \mathrm{ml}$ to $\mathrm{mg} / \mathrm{m}^{3}$ is impossible as the type of talc used is not specified. Of particular interest is the mortality study of Thomas ${ }^{12}{ }^{13}$ among ceramic workers exposed to quartz and non-fibrous talc. Unfortunately no quantitative estimate of either exposure is available and no quartz free group could be identified. Langseth et $a l^{20}$ and Bulbulyan et $a l^{19}$ mention talc exposure as part of the paper dust exposure, talc being sometimes used as filler in paper production.

Table 2 Summary characteristics of talc exposed populations in other industries

\begin{tabular}{|c|c|c|c|c|}
\hline & Cohort definition & Talc exposure & Other & Smoking \\
\hline $\begin{array}{l}\text { Thomas et al, pottery } \\
\text { workers }\end{array}$ & $\begin{array}{l}\text { All employees of three US ceramic factories } \\
\text { with one year employment 1939-66 followed } \\
\text { up from 1955-81 }\end{array}$ & No, non-fibrous, fibrous & Quartz high/low & No information \\
\hline $\begin{array}{l}\text { Zhang et al, rubber } \\
\text { workers }^{14}\end{array}$ & $\begin{array}{l}\text { Employees (male and female) of a Shanghai } \\
\text { rubber factory who entered a screening } \\
\text { program for heart disease in } 1972 \\
\text { followed up from 1972-84 }\end{array}$ & $\begin{array}{l}\text { Exposure during curing. } \\
\text { No precision as to whether } \\
\text { fibrous or not fibrous }\end{array}$ & $\begin{array}{l}\text { Curing agents, condensed } \\
\text { volatiles, gases } \\
\text { nitrosamines }\end{array}$ & $\begin{array}{l}\text { Available for } \\
\text { everybody, } \\
\text { controlled in the } \\
\text { analysis }\end{array}$ \\
\hline $\begin{array}{l}\text { Chiazze et al, } \\
\text { fibreglass workers }\end{array}$ & $\begin{array}{l}\text { Production and maintenance workers } \\
\text { employed at least one year in a Ohio } \\
\text { fibreglass plant from 1940-62, followed } \\
\text { up until } 1982\end{array}$ & $\begin{array}{l}\text { Expressed in estimated } \mathrm{f} / \mathrm{ml} \text {. } \\
\text { No precision as to whether } \\
\text { fibrous or not fibrous }\end{array}$ & Asbestos, silica, formaldehyde, & $\begin{array}{l}\text { Available for } \\
\text { everybody, } \\
\text { controlled in the } \\
\text { analysis }\end{array}$ \\
\hline $\begin{array}{l}\text { Straif et al, rubber } \\
\text { workers }\end{array}$ & $\begin{array}{l}\text { All male employees from five German rubber } \\
\text { plants with at least one year employment retired } \\
\text { or active in } 1981 \text { followed up from 1981-91 }\end{array}$ & $\begin{array}{l}\text { Low/medium/high } \\
\text { Non-fibrous talc }\end{array}$ & $\begin{array}{l}\text { Asbestos, nitrosamines, carbon } \\
\text { black }\end{array}$ & No information \\
\hline $\begin{array}{l}\text { Langseth and } \\
\text { Andersen, paper } \\
\text { workers }^{20}\end{array}$ & $\begin{array}{l}\text { All female employees of a pulp and paper mill } \\
\text { working at least one year between 1920-93 } \\
\text { followed up for cancer incidence from 1953-93 }\end{array}$ & $\begin{array}{l}\text { As a constituent of paper dust } \\
\text { in the paper departments }\end{array}$ & $\begin{array}{l}\text { Paper dust, sulphur dioxide, } \\
\text { hydrogen sulphide, chlorine, } \\
\text { chlorine dioxide }\end{array}$ & No information \\
\hline $\begin{array}{l}\text { Bulbulyan et al, } \\
\text { printing workers }^{19}\end{array}$ & $\begin{array}{l}\text { All female employees of two printing plants } \\
\text { working at least two year between 1978-93 } \\
\text { followed up for cancer incidence from 1979-93 }\end{array}$ & $\begin{array}{l}\text { As a constituent of paper dust } \\
\text { in the book binding department } \\
\text { and among press operators }\end{array}$ & $\begin{array}{l}\text { Paper dust, benzene, } \\
\text { solvents, aromatic hydrocarbons, } \\
\text { carbon black }\end{array}$ & No information \\
\hline
\end{tabular}


Table 3 Lung cancer and mortality from all causes in the talc producing companies

\begin{tabular}{|c|c|c|c|c|c|}
\hline & \multirow[b]{2}{*}{$\mathbf{n}$} & \multicolumn{3}{|l|}{ Lung cancer } & \multirow{2}{*}{$\begin{array}{l}\text { Mortality, } \\
\text { all causes }\end{array}$} \\
\hline & & Type of RR & RR (cases) & $95 \% \mathrm{Cl}$ & \\
\hline \multicolumn{6}{|l|}{ Talc millers } \\
\hline Vermont $^{4}$ & 225 & SMR US rates & $1.02(2)$ & $0.09-3.69$ & $1.18(44)$ \\
\hline Norway ${ }^{15}$ & 295 & SIR Norwegian rates & $0.77(4)$ & $0.21-1.96$ & $0.74(90)$ \\
\hline Italy ${ }^{22}$ & 551 & SMR regional rates & $0.69(11)$ & $0.34-1.23$ & $1.08(290)$ \\
\hline France $^{21}$ & 945 & SMR regional rates & $1.24(21)$ & $0.76-1.89$ & $0.93(294)$ \\
\hline Austria, sit & & SMR regional rates & $0.69(3)$ & $0.14-2.01$ & $0.70(40)$ \\
\hline Austria, sit & & SMR regional rates & $1.11(1)$ & $0.01-6.19$ & 0.97 (11) \\
\hline All talc mil & fect & & $0.92(42)$ & $0.67-1.25$ & $0.95(769)$ \\
\hline \multicolumn{6}{|c|}{ Talc miners } \\
\hline Vermont $^{4}$ & 163 & SMR US rates & $4.35(5)$ & $1.40-10.2$ & $1.28(34)$ \\
\hline Norway ${ }^{15}$ & 94 & SIR Norwegian rates & $1.58(2)$ & $0.18-5.69$ & $0.82(27)$ \\
\hline Italy ${ }^{22}$ & 1244 & SMR regional rates & $1.07(33)$ & $0.74-1.50$ & $1.26(590)$ \\
\hline \multicolumn{3}{|c|}{ All talc miners - fixed effect } & $1.20(40)$ & $0.86-1.63$ & $1.24(651)$ \\
\hline \multicolumn{3}{|c|}{ All talc miners-random effect } & $1.85(40)$ & $0.68-5.05$ & $1.10(651)$ \\
\hline
\end{tabular}

It must be noted that neither Zhang et al, nor Bulbulyan et al, nor Chiazze et al mention whether or not the talc used contained asbestiform fibres. The talc used in the Norwegian paper mill can be supposed to be free of asbestiform fibres assuming that this producer used European talc paralleling a similar argument used by Straif et al. ${ }^{17}$

Table 3 gives the summary mortality results of the talc millers and miners. Among millers, in which no other carcinogen is mentioned, only one RR (in the French cohort) was above unity but not significantly so. Moreover in this population, an internal case control study showed no increasing trend with cumulative exposure. Overall the SMR among millers is equal to 0.92 (95\% CI 0.65 to 1.25 ) and below the SMR for all causes and no heterogeneity between the studies was detected $\left(\chi^{2}=3.21,5 \mathrm{df}, \mathrm{p}=0.67\right)$.

If we rank the observed SMRs by increasing global exposure based on the fragmentary exposure information available as given in the preceding section, we observe a slight non-significant increase from the SMR of the Italian millers ( 0.67 presumed to have the lowest exposure) to the SMR of the French millers (1.24) presumed to have the highest exposure. Of somewhat better precision is the doseresponse relation explored in a nested case control study in the French and Austrian cohort. ${ }^{21}$ The odds ratios decreased with increasing cumulative talc exposure, the odds ratios with respect to non-talc exposed subjects exposed from 400800 years $\times \mathrm{mg} / \mathrm{m}^{3}$ was 0.60 and for subjects above
800 years $\times \mathrm{mg} / \mathrm{m}^{3}$ it was 0.73 . The latter subjects correspond to a job held for more than 20 years in the highest exposure category $\left(>30 \mathrm{mg} / \mathrm{m}^{3}\right)$. Note also that the mortality from lung cancer does not increase by duration of employment among Italian millers and miners. ${ }^{22}$

Among miners for whom exposures to quartz and radon are mentioned, the only significant increase is in the Vermont talc miners. Overall the SMR among miners is 1.20 (95\% CI 0.86 to 1.63 ) and is close to the SMR for all causes. However a significant heterogeneity was detected, owing to the very large risk among Vermont miners $\left(\chi^{2}=10.1, \mathrm{df}=2\right.$, $p=0.006)$. The random effect summary estimate is therefore larger with a wider confidence interval $(\mathrm{RR}=1.85,95 \% \mathrm{CI}$ 0.68 to 5.05 ).

Table 4 summarises the relative risks with respect to talc exposures in other industries. Overall all relative risks are above unity but only in the study of Chiazze et $\mathrm{al}^{16}$ was the talc exposure adjusted on the major confounders. The highest risks are seen in the US ceramic industry in which the SMRs increased with increasing duration to non-fibrous talc exposure but not with silica. No combined estimate was computed as the studies differ too much in the exposure circumstances.

\section{DISCUSSION}

The preceding analyses show that in the populations of talc millers in which talc was (nearly) the single exposure, lung

Table 4 Lung cancer relative risks in relation to talc exposure in other industries

\begin{tabular}{|c|c|c|c|c|}
\hline & \multirow[b]{2}{*}{$\mathbf{n}$} & \multicolumn{3}{|l|}{ Lung cancer } \\
\hline & & Type of relative risk & RR (exposed cases) & $95 \% \mathrm{Cl}$ \\
\hline \multirow[t]{2}{*}{ Ceramic industry, US ${ }^{1213}$} & 2055 & $\begin{array}{l}\text { SMR ever exposed to non-fibrous talc and high silica } \\
\text { (US rates)-unadjusted }\end{array}$ & $2.54(21)$ & $1.57-3.88$ \\
\hline & & $\begin{array}{l}\text { SMR exposed to } 15+\text { years non-fibrous talc and high silica } \\
\text { (US rates)-unadjusted }\end{array}$ & $3.64(8)$ & $1.57-7.17$ \\
\hline Rubber industry, China ${ }^{14}$ & 1624 & Mantel-Haenszel RR (rubber curing adjusted on smoking) & $\begin{array}{l}\text { Males } 3.3(7) \\
\text { Females } 4.6(2)\end{array}$ & $\begin{array}{l}1.3-8.2 \\
0.8-28.0\end{array}$ \\
\hline \multirow[t]{2}{*}{ Rubber industry, Germany ${ }^{17} 18$} & 8933 & Internal RR (high talc exposure unadjusted) & $2.4(13)$ & $1.2-4.9$ \\
\hline & & $\begin{array}{l}\text { Internal RR (high talc or asbestos exposure adjusted on } \\
\text { smoking and other exposures) }\end{array}$ & $2.0(13)$ & $0.9-4.1$ \\
\hline Glass fibre production, $\mathrm{US}^{16}$ & $\begin{array}{l}144 \text { cases, } \\
280 \text { controls }\end{array}$ & $\begin{array}{l}\text { OR (high talc exposure adjusted on smoking and other } \\
\text { exposures) }\end{array}$ & $1.36(10)$ & $0.41-4.52$ \\
\hline Printing industry, Russia ${ }^{19}$ & 1795 & $\begin{array}{l}\text { SMR (in press operators and in bookbinders exposed to } \\
\text { paper dust potentially containing talc) }\end{array}$ & $1.0(6)$ & $0.35-2.18$ \\
\hline Pulp and paper mill, Norway ${ }^{20}$ & & $\begin{array}{l}\text { SIR (all workers with more than three years employment, } \\
\text { at least } 44 \% \text { of which have been exposed to paper dust } \\
\text { potentially containing talc) }\end{array}$ & $1.4(14)$ & $0.70-2.16$ \\
\hline
\end{tabular}


cancer risk was not increased; the upper limit of the confidence limit being 1.25. On the other hand, in the presence of other carcinogens, in talc miners and in other settings, some excesses appeared.

Are the latter risks attributable to non-fibrous talc? In all these populations other potential occupational carcinogens co-exist with talc, thus all unadjusted relative risks are confounded to some degree. The study of Zhang et al ${ }^{14}$ appears difficult to interpret as a study of talc exposure as it considered only working in the curing workshop as a risk factor. Curing rubber involves other possibly carcinogenic exposures especially exposure to nitrosamines. A later follow up of the same population ( $\mathrm{Li}$ et $a l^{23}$ ) privileged this hypothesis. Furthermore it is not possible to tell whether the talc used contained asbestiform fibres. A similar feature occurs with the German rubber workers (Straif et al ${ }^{17}{ }^{18}$ ). While the unadjusted relative risks with talc alone are increased and significant in this paper and some confounding with nitrosamines and asbestos is likely, the adjusted risks are only given for a combined asbestos and talc exposure. Thus the relative effect of these two exposures cannot be distinguished. The odds ratio of 1.36 after adjustment for smoking and a series of occupational exposure computed by Chiazze $^{16}$ is a rather weak evidence, especially as the unadjusted risk was below unity. The papers by Bulbulyan ${ }^{19}$ and Langseth ${ }^{20}$ mention a talc exposure as a component of paper dust. Following the recent worldwide multicentric IARC study in the pulp and paper industry, a number of nationwide mortality studies have been published (for example, see Szymczak et al, Sivo et al, Wild et al, and Matanoski et a ${ }^{25-28}$ ) most of which do not mention talc exposure. However the subpopulations of these studies involved in paper production could be considered to be talc exposed. Moreover, in the unpublished final report of the IARC multicentric study, the lung cancer mortality of subjects in the pulp and paper industry ever exposed to talc (286 observed cases $v 295$ expected) or ever highly exposed to talc (59 cases $v 61.6$ expected) was not in excess. However significantly increased lung cancer SMRs are observed in the subset of talc exposed women in the same report. Stronger evidence as to a possible carcinogenic effect of talc is provided by the paper of Thomas and Stewart ${ }^{12}$ as a increasing trend with duration of non-fibrous talc exposure was observed, which was not observed for silica. However no quartz free talc exposure group could be identified in this cohort and the authors "do not rule out the effect of silica as a cofactor". Moreover the authors acknowledge that talc containing fibres had also been in use. In the light of these very different features a pooled risk estimate did not seem relevant.

Can the absence of lung cancer risk among talc millers be explained by healthy worker effect or by lack of control for smoking? As shown in table 3, the combined SMR for all causes is close to unity and is higher than the SMR for lung cancer. Thus a decreased SMR because of a healthy worker effect and/or inappropriate reference rates is highly unlikely. For four out of five studies some smoking data are available and, with the possible exception of the Austrian millers, the available data point towards a smoking prevalence which is higher than in the reference population. This is not unexpected among blue collar workers. Thus it is highly unlikely that the absence of information on smoking in the mortality studies could have hidden a risk due to talc. On the other hand, most of the talc worker cohorts include all employees of the mills and mines, so that it is likely that a number of unexposed subjects were included. This has probably lowered some of the SMRs but the impact of this necessarily small population on the cited SMRs should be virtually negligible.
What is the strength of this evidence? The weight of this (negative) evidence is to a large extent dependent on the overall exposure and its characterisation. Unfortunately in most studies only very sketchy exposure information is given and only SMRs are given without any attempt to estimate possible exposure-response relations. However, it can be safely assumed that the exposure was high and sometimes extremely so in most populations of talc millers. This high exposure is documented by the fact that in all studied talc exposed populations cases of pneumoconiosis were observed. Although no miller died of non-malignant respiratory diseases (NMRD) in the Norwegian population and only one in the Austrian population, the past prevalence of pneumoconiosis was high in both populations. This contrasted with a high mortality from NMRD among Vermont millers $^{4}$ (SMR $=4.1$, seven cases $)$. In Italy ${ }^{22}$ and France ${ }^{21}$ the mortality from NMRD was slightly above the expected ( $\mathrm{SMR}=1.04$ and 1.06 respectively) but in the latter population a significantly increasing trend could be shown: in the two highest exposure categories for which the lung cancer odds ratios were below unity (see results section) the ORs for NMRD increased significantly at respectively 1.97 and 2.53, thus validating the high talc exposure in these categories. The overall evidence of this absence of risk is further strengthened by the fact that no heterogeneity between the lung cancer SMRs among talc millers could be observed. However the main weakness of these data is the paucity of reliable studies of a possible dose-response effect.

What is the influence of a possible publication bias? It is unlikely that a cohort study conducted among talc workers would have gone completely unpublished if it showed an increased lung cancer risk. There has been a public awareness of a possible carcinogenic risk with respect to talc since the publication of the study by Kleinfeld et $a^{29}$ and the number of talc producing sites in quite limited. On the other hand the description of small cohorts may go unpublished if no risk is shown-for example, the site by site description among Austrian miners could not be published. Note that the mortality of the Norwegian talc workers is currently being updated (personal communication of Dr Wergeland).

A publication bias is more likely for the studies carried out in other industrial settings. Given the widespread use of talc in many industrial applications (paper, paints, plastics, rubber, ceramics, and so on) it is surprising that only six studies considered talc exposure as a potential carcinogen. One cannot exclude that negative results-that is, studies in which talc could not be shown to increase the lung cancer risk-were not included in necessarily condensed published papers.

The epidemiological evidence concerning a possible lung cancer relation must be considered in the light of the evidence from other human and animal studies. Talc has been suspected to be a human carcinogen based on the fact that talc powders contain a significant number of particles which meet the WHO definition of a fibre, and that these particles are very biopersistent and that persistent fibres have shown tumorigenic effects. This hypothesis does not seem to be supported by the available animal and vitro studies. The lung cancer excesses observed in a large chronic rat inhalation assay conducted by the NTP are interpretable as being the result of inflammation causing secondary genotoxicity on the basis of the well recognised phenomenon of lung overload in rats by poorly soluble low toxicity particles (Oberdörster et $a l^{30}$ Knaapen et $a l^{31}$ ). Thus this study does not give any indication as to a specific carcinogenicity of talc. Other studies using intrapleural instillation of high doses of talc (Wagner, ${ }^{32}$ Stanton $^{33}$ ) did not show any carcinogenic effect. This is consistent with results of a recent in vitro study by Nasreen ${ }^{34}$ who describes how a talc sample at low doses 


\section{Main message}

- There is no evidence of an increased lung cancer risk among workers exposed to talc not containing asbestiform fibres in the absence of other potential carcinogens.

$\left(6 \mu \mathrm{g} / \mathrm{cm}^{2}\right)$ was able to cause apoptosis of malignant but not normal mesothelial cells. This selective apoptotic effect may also be the reason why humans who were treated with massive amounts of talc (5-10 g) for pleurodesis did not show chronic complications such as mesothelioma or lung cancer in the single follow up study of treated patients. ${ }^{35}$

Finally, a large literature exists on the potential relation between talc exposure and ovarian cancer. A recent metaanalysis $^{36}$ found a significantly increased summary relative risk, $\mathrm{RR}=1.33(95 \%$ CI 1.16 to 1.45$)$. However the authors stated that "the data showed a lack of clear dose-response relationship making the RRs of questionable validity". It can also be remarked that some of the cosmetic talc powders in the US had been shown to contain asbestiform fibres in the past.

\section{CONCLUSION}

No increased lung cancer mortality was observed among talc millers despite their high exposure experience. However few studies provide adequate exposure information. Further studies of possible quantitative exposure-response relations are needed. In populations in which talc was associated with other potential carcinogens, some lung cancer excesses were observed.

\section{ACKNOWLEDGEMENTS}

We thank Dr Coggiola for the communication of smoking and exposure data among the Italian talc workers, Professor Haidinger and Dr Schmidt for detailed information concerning the Austrian talc workers, and Dr Wergeland for providing information on the Norwegian talc workers. We acknowledge also helpful comments of Dr Morfeld on an earlier draft of this paper, the contribution of Dr Ferret on mineralogy, and of Professor Oberdörster on the animal studies.

Competing interests: none declared.

\section{REFERENCES}

1 Rohl AN, Langer AM, Selikoff IJ. Consumer talcums and powders: mineral and chemical characterization. J Toxicol Environ Health 1976;2:255-84.

2 Deer WA, Howie HA, Zussman J. Rock-forming minerals. Vol 3 Sheet Silicates. New York Longman, Green \& Co, 1962:1-120.

3 International Agency for Research on Cancer. IARC monograph on the evaluation of carcinogenic risks to humans. Silica and some silicates. Lyon, 1987;42: 122-224 and Suppl 7, p349).

4 Selevan SG, Dement JM, Wagoner JK, et al. Mortality patterns among miners and millers of non-asbestiform talc: preliminary report. J Environ Pathol Tox 1979;2:273-84.

5 Rubino GF, Scansetti G, Piolatto G, et al. Mortality and morbidity among talc miners and millers in Italy. In: Lemen R, Dement JM, eds. Dusts and disease. Park Forest South, Illlinois: Pathodox Publisher, Inc, 1979:257-363.

6 Léophonte P, Basset MF, Pincemin J, et al. Mortality of talc workers in France. Rev Fr Mal Resp 1983;11:489-90.
7 Katsnelson BA, Mokronosova KA. Non-fibrous mineral dusts and malignant tumors. An epidemiological study of mortality. J Occup Med 1979;21:15-20.

8 Breslow NE, Day NE. Statistical methods in cancer research, Vol II: Design and analysis of cohort studies. IARC: Lyon, France, 1987;(Scientific Publication No 82):91-6.

9 Sutton AJ, Abrams KR, Jones DR, et al. Methods for meta-analysis in medical research. J Wiley and Sons, Chichester, 2000:74-75

10 Stern F, Lehman E, Ruder A. Mortality among unionized construction plasterers and cement masons. Am J Ind Med 2001;39:373-88.

11 McDonald JC, Armstrong B, Case B, et al. Mesothelioma and asbestos fiber type. Evidence from lung tissue analyses. Cancer 1989;63:1544-7.

12 Thomas TL, Stewart P. Mortality from lung cancer and respiratory disease among pottery workers exposed ti silica and talc. Am J Epidemiol 1987; 125:35-43.

13 Thomas TL. Lung cancer mortality among pottery workers in the United States. IARC Sci Publ 1990;97:75-81.

14 Zhang ZF, Yu SZ, Li WX, et al. Smoking, occupational exposure to rubber, and lung cancer. $\mathrm{Br} J$ Ind Med 1989;46:12-15.

15 Wergeland E, Andersen A, Baerheim A. Morbidity and mortality in talcexposed workers. Am J Ind Med 1990;17:505-13.

16 Chiazze L, Watkins DK, Fryar C, et al. A case-control study of malignant and non-malignant respiratory disease among employees of a fibreglass manufacturing facility. II Exposure assessement. Br J Ind Med 1993;50:717-25

17 Straif K, Chambless L, Weiland SK, et al. Occupational risk factors for mortality from stomach and lung cancer among rubber workers: an analysis using internal controls and refined exposure assessment. Int J Epidemiol 1999;28:1037-43.

18 Straif K, Keil U, Taeger D, et al. Exposure to nitrosamines, carbon black, asbestos, and talc and mortality from stomach, lung, and laryngeal cancer in a cohort of rubber workers. Am J Epidemiol 2000;152:297-306.

19 Bulbulyan MA, llychova SA, Zahm SH, et al. Cancer mortality among women in the Russian printing industry. Am J Ind Med 1999;36:166-71.

20 Langseth $\mathrm{H}$, Andersen A. Cancer incidence among women in the Norwegian pulp and paper industry. Am J Ind Med 1999;36:108-13.

21 Wild $\mathbf{P}$, Leodolter K, Refrégier $M$, et al. A cohort mortality and nested casecontrol study of French and Austrian talc workers. Occup Environ Med 2002;59:98-105

22 Coggiola $M$, Bosio D, Pira $E$, et al. An update of a mortality study of talc miners and millers in Italy. Am J Ind Med 2003:44:63-9.

23 Wild P, Refrégier M, Auburtin G, et al. Survey of the respiratory health of the workers of a talc producing factory. Occup Environ Med 1995;52:470-7.

24 Li K, Yu S. Economic status, smoking, occupational exposure to rubber, and lung cancer: a case-cohort study. J Environ Sci Health C Environ Carcinog Ecotoxicol Rev 2002;20:21-8.

25 Szymczak W, Szadkowska-Stanczyk I. Quantitative assessment of lung cancer risk in men employed in the pulp and paper industry in Poland Int J Occup Med Environ Health 2004;17:263-72.

26 Sivo D, Bisceglia L, de Nichilo G, et al. Mortality among workers employed in the production of pulp and paper in Apulia. G Ital Med Lav Ergon 2003;25:24-25 [in Italian].

27 Wild P, Bergeret A, Moulin JJ, et al. Mortality in the French paper and pulp industry. Rev Epidemiol Sante Publique 1998:46:85-92 [in French].

28 Matanoski GM, Kanchanaraksa S, Lees PS, et al. Industry-wide study of mortality of pulp and paper mill workers. Am J Ind Med 1998;33:354-65.

29 Kleinfeld M, MessiteJ, Zaki MH. Mortality experience among talc workers: a follow-up study. J Occup Med 1974;16:345-9.

30 Oberdörster G. The NTP talc inhalation study: A critical appraisal focused on lung particle overload. Regul Toxicol Pharmacol 1995;21:233-41.

31 Knaapen A, Borm PJA, Albrecht C. Inhaled particles and lung cancer. Part A: Mechanisms. Int J Cancer 2004;109:799-809.

32 Wagner JC, Berry G, Cooke TJ, et al. Animal experiments with talc. Inhaled Part 1975;4:647-54.

33 Stanton MF, Layard M, Tegeris A, et al. Relation of particle dimension to carcinogenicity in amphibole asbestoses and other fibrous materials. J Nat Cancer Inst 1981;67:965-75.

34 Nasreen N, Mohammed KA, Dowling PA, et al. Talc induces apoptosis in human malignant mesothelioma cells in vitro. Am J Crit Care Med 2000;161:595-600.

35 Research Committee of the British Thoracic Association and the Medical Research Council Pneumoconiosis Unit. A survey of the long-term effects of talc and kaolin pleurodesis. Br J Dis Chest 1979;73:285-8.

36 Huncharek M, Geschwind JF, Kupelnick B. Perineal application of cosmetic talc and risk of invasive epithelial ovarian cancer: a meta-analysis of 11,933 subjects from sixteen observational studies. Anticancer Res 2003;23:1955-60. 